УДК 504.9

Доц. А.Б. Тарнавський, канд. техн. наук; доц. У.В. Хром'як, канд. техн. наук - Львівський ДУ безпеки життєдіяльності

\section{ЗАЛУЧЕННЯ ПІДРОЗДІЛІВ ДЕРЖАВНОЇ СЛУЖБИ З НАДЗВИЧАЙНИХ СИТУАЦІЙ ДО РОЗМІНУВАННЯ ТА РЕКУЛЬТИВАЦІЯ ТЕРИТОРІЙ ПОРУШЕНИХ ВНАСЛІДОК ВОЄННИХ ДІЙ НА СХОДІ УКРАЇНИ}

На сьогодні однією з основних характеристик техногенного впливу на навколишнє середовище у Східній Україні є довготривалі воєнні дії, які призводять до негативних змін у довкіллі. Проблема розмінування територій проведення бойових дій та утилізації боєприпасів, що не розірвалися, є досить гострою. Проаналізовано основні негативні наслідки застосування бойовиками мін, снарядів і наведено основні організаційні заходи шодо їх знешнодження. Подано інформанійні дані шодо наявності у грун деяких населених пункт донбасу поксичних вармай деяких населених пунктів Донбасу токсичних важких металів після проведення артилерійських обстрілів. Запропоновано основний комплекс робіт з відновлення зруйнованоі
території. ериторії.

Ключові слова: воєнні дії, Східна Україна, міни, мінні поля, розмінування, піротехнічні підрозділи, важкі метали, забруднення, грунт, рекультивація, навколишнє середовище.

Постановка проблеми. Будь-які воєнні дії призводять до негативного впливу на навколишнє середовище. На цей час немає комплексних досліджень, у яких було б чітко проаналізовано численні збитки, що завдані бойовими діями на території Донбасу навколишньому природному середовищу. На Сході України екологічна ситуація ще до початку воєнних дій була критичною: велика кількість промислових підприємств, неочищені викиди відпрацьованих промислових газів та скиди стічних вод, закинуті і затоплені шахти із небезпечними речовинами, а саме відходами хімічних виробництв [1].

У той час, коли у Донецькій та Луганській обл. відбувалася війна, екологічних проблем стало набагато більше і вони досягли критичного рівня. До них можна віднести руйнування природного ландшафту внаслідок обстрілів із реактивних систем залпового вогню "Град", забруднення водних об'єктів і ризик виникнення техногенної катастрофи, якщо один із випущених снарядів влучить у промисловий об'єкт з наявністю хімічно небезпечних речовин [2].

Після війни на Донбасі Україна зіштовхнеться 3 потребою проведення глобального розмінування місцевості на територіях проведення бойових дій. Причому цей процес може затягнутися на десятиліття $[3,4]$ і буде ускладнюватися тим, що здебільшого мінні загородження і поля встановлювали безграмотно і без складання карт мінних полів [5].

Результати. На сьогодні для України існує три варіанти проведення розмінування території проведення бойових дій на Донбасі [5]. Перший варіант це одночасно із миротворчим контингентом Україна має просити міжнародну підтримку і запрошувати спеціалістів з розмінування. Другий варіант полягає в укладанні прямих контрактів із приватними іноземними військовими компаніями на розмінування своєї території. Згідно з третім варіантом Україна має проводити розмінування власними силами.

На цей момент для України найбільш вигідним є проведення розмінування силами і засобами власних спеціалістів, адже залучення міжнародних фахівців є довгим і бюрократичним процесом, який може затягнутися на тривалий час. Поряд 3 цим, укладати прямі договори з іноземними компаніями з розмінування є доволі дорого. Так, наприклад, Хорватія у період з 1998 по 2005 pp. 3 цією метою витратила понад 240 млн дол.

Проте не варто забувати, що з 2001 р. у Кам'янець-Подільському Хмельницької обл. [6] створено й успішно проводить підготовку саперів єдиний в Україні Центр розмінування Збройних сил. Його спеціалісти успішно зарекомендували себе під час миротворчої місії в Лівані і під час війни в Іраку. Проте, яку б модель розмінування своєї території не обрала Україна, вона не буде ефективною без передачі сторонами конфлікту карт мінних полів у єдиний координаційний центр. Адже міни і "розтяжки" регулярно знаходять на підконтрольних територіях ДНР та ЛНР, а також у прифронтових містах і селищах з української сторони мало не щодня [5]. Проблем додають також і місцеві мешканці, а особливо діти, які після завершення бойових дій іноді збирають вибухонебезпечні предмети, що не розірвалися, у вигляді мін і гранат на трофеї [3, 4]. За даними $\mathrm{OOH}$, із березня минулого року у Донецькій і Луганській обл. від нещасних випадків, які пов'язані із мінами і боєприпасами, загинуло щонайменше 42 дитини, ще 109 було поранено [7].

Піротехнічний загін ДСНС України з 06.07.2014 р. здійснює роботи із гуманітарного розмінування території та об'єктів інфраструктури Донецької та Луганської обл. Першочергово здійснюють розмінування населених пунктів, зокрема дитячих дошкільних і навчальних закладів, промислових об'єктів із газо-, тепло-, енерго- та водопостачання 3 метою відновлення їх нормального функціонування. 3 початку виконання робіт (06.07.2014р.) піротехніки ДСНС України очистили від боєприпасів, мін та інших снарядів понад 1650 га теритоpiї та 38 га акваторії водних об'єктів, розмінували понад 1 тис. житлових будівель та промислових споруд [8]. Окрім цього, за даними ДСНС, всього протягом минулого року українські піротехніки виявили і знешкодили близько 151 тис. вибухонебезпечних предметів, майже 34 тис. 3 яких було знешкоджено у зоні АТО. Під час виконання завдань було знешкоджено та утилізовано понад 600 особливо небезпечних вибухових пристроїв, зокрема підривні засоби із дистанційним керуванням, боєприпаси на розтяжках у стані невилучення, фугаси великої потужності, протитанкові та протипіхотні міни. Проте найбільше шокують вибухові пристрої, які цинічно замасковані під предмети побуту та дитячі іграшки, які насамперед призначені для травмування дітей $[4,8]$.

До виконання завдань із розмінування території Донбасу залучено близько 200 піротехніків ДСНС. Для цього ДСНС України розробила План гуманітарного розмінування місцевості Донецької та Луганської обл. на 2015 р. Орієнтовна площа територій, що потребують розмінування, становить приблизно 7 тис. км ${ }^{2}$. Для постійного виконання завдань із розмінування з березня по листопад 2015 р. було залучено одночасно 250 фахівців та 50 од. спецтехніки, 3 урахуванням ротацій до виконання заходів залучатиметься до 500 людей особового складу [8].

30.07.2015 р. ДСНС України уклала спільний проект з ОБСЄ "Допомога уряду України в очищені території на сході України від залишків війни" про поставку технічної допомоги для розмінування території Донецької та Лугансь-

2. Екологія та довкілля 
кої обл. [9]. Загальна вартість проекту становила 995 тис. євро. Донором цього проекту стала Німеччина. ДСНС спільно з ОБСС склали та погодили перелік обладнання для оснащення 4-х піротехнічних розрахунків ДСНС загальною чисельністю 22 людини особового складу. Проект розрахований на поставку технічних засобів для проведення розмінування. Це автомобілі для перевезення вибухонебезпечних предметів (Ford F-550 пікап), вибухозахисні костюми важкого типу для піротехніків, інші засоби індивідуального захисту (шоломи, захисні окуляри, наколінники), засоби пошуку вибухонебезпечних предметів (бомбошукачі, металодетектори), групові та індивідуальні засоби забезпечення проведення робіт з розмінування, засоби зв'язку та інші допоміжні кошти. У рамках проекту також будуть проводити тренінги для піротехніків ДСНС щодо отриманого від ОБСЄ обладнання, розвідки та знешкодження вибухонебезпечних предметів, міжнародних стандартів протимінної діяльності, підготовки керівного складу піротехнічних підрозділів. Крім того, спеціальна моніторингова місія ОБСЄ має намір мінімізувати свою присутність у деяких районах Донецької та Луганської обл. через потрапляння під обстріл. Співпраця в рамках цього проекту буде тривати півтора року.

На початку березня 2015 р. піротехніки ДСНС на прохання аграріїв розпочали розмінування сільськогосподарських ділянок на Донбасі. За заявками аграріїв було виконано роботи з обстеження сільськогосподарських угідь у Волноваському, Першотравневому й Артемівському районах Донецької обл. Щодня на цих територіях піротехніки знаходять від 5 до 10 одиниць вибухонебезпечних предметів [10]. I це не тільки залишки снарядів і мін, що залишили по собі терористи, а й небезпечні предмети періоду Другої світової війни. На сьогодні на Донеччині від снарядів і мін з початку року звільнено територію понад 1500 га. У Донецькому аеропорту та його околицях знаходиться дуже багато боєприпасів, що не вибухнули [11]. За попередньою оцінкою ДСНС, наразі необхідно знешкодити понад 75 тис. боєприпасів і вибухонебезпечних предметів.

Науковці провели дослідження на наявність шкідливих речовин у грунті низки населених пунктів Донецької обл., які постраждали від артобстрілів. Це, зокрема, села Піски, Опитне, Мінеральне та Веселе Ясиноватського р-ну, Кременець Мар'їнського р-ну і в районі Донецького аеропорту. Проби грунту, які взято у воронках від артилерійських снарядів і в безпосередній близькості від них показали перевищення допустимої фонової норми у кілька разів таких важких металів як: марганець, мідь, залізо, свинець, кадмій, хром, олово, галій, нікель, титан, ітрій, цирконій, кобальт, стронцій і цинк. Так, наприклад, перевищення фонових концентрацій за вмістом міді у Мінеральному становило 1,2 1,4 рази, марганцю у Веселому та в районі Донецького аеропорту - у 14-1,6 разів. У воронках від снарядів у Кременці вміст свинцю у грунті перевищив норму у 8,1-8,3 разів, в Опитному та Донецькому аеропорті - у 1,7-1,9 разів, а у Веселому - у 1,5-1,7 разів. На території Мінерального вміст кадмію перевищив норму у 2,4-2,6 разів, а в районі Донецького аеропорту - більше як у 12 разів. Перевищення вмісту важких металів понад нормовані значення у грунті за важкими металами в Опитному становило: за цинком - 3,1-3,3 рази, за залізом $10,7-10,9$ разів, за марганцем - 3,2-3,4 рази, за міддю - 2,3-2,5 рази, за хромом -
1,8-2,0 рази. У пробах грунту в районі Мінерального було виявлено перевищення вмісту ітрію у 2,8-3,0 рази.

На думку екологів, вирощувати будь-які сільськогосподарські культури поблизу артилерійських воронок $є$ надзвичайно небезпечно для здоров'я. Важкі метали можуть сотні років не виводитися з грунту. Поряд 3 цим, треба зазначити, що під час вибуху снаряду можуть утворюватися токсичні органічні речовини, які потоками вітру та підземними водами поширюватимуться на значні території. Потрапляючи в організм людини, ці метали практично не виводяться 3 нього, спричиняючи цим самим захворювання нервової, репродуктивної, серцево-судинної систем, уражаючи печінку і нирки.

Так, наприклад, свинець належить до речовин, що мають властивість акумулюватися в організмі людини. Потрапляючи з їжею в організм, частинки свинцю у шлунку при взаємодії з соляною кислотою перетворюються у хлорид свинцю, який добре розчиняється і всмоктується у кров. Потрапивши у кров, свинець циркулює у вигляді сполук - фосфату й альбуміну, що перебуває у колоїдному стані. Основними ознаками ураження свинцем є важкі порушення роботи нервової і травної систем, нирок та інших органів: головний біль, запаморочення, холодний піт, солодкуватий металевий присмак у роті, слинотеча, втрата апетиту, нудота, іноді блювання, біль і слабкість у ногах, зниження гостроти зору, безсоння.

Марганець швидко всмоктується в кров та циркулює в ній у вигляді нестійкого комплексу з білками. Під час потрапляння марганцю в організм він спричиняє важкі розлади кровообігу, різку задишку, знепритомнення. У легких випадках отруєння відбувається подразнення слизової оболонки дихальних шляхів, кашель, головний біль. Сполуки марганцю проявляють високоалергічні властивості, що зумовлює розвиток хронічного бронхіту з вираженим астматичним компонентом, а також - бронхіальної астми. Якщо на городі розірвався снаряд, ракета або міна, екологи наполегливо рекомендують зняти верхній шар грунту перед висадженням овочів. У разі, якщо на місці, де була воронка (рис. 1), овочі вже дозріли, вчені радять відмовитися від приймання цих продуктів у їжу.

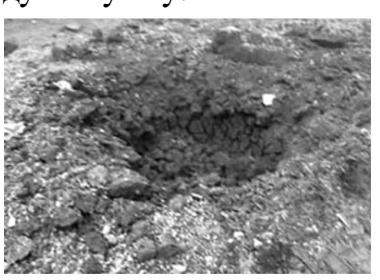

$a$

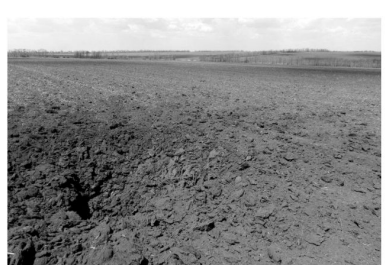

б

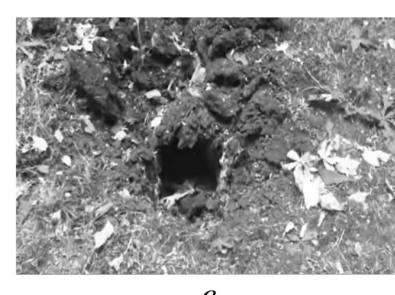

Рис. 1. Місия падіння снарядів на присадибних ділянках: а) мінометна міна 120 мм, б) артилерійський снаряд 152 мм; в) реактивний снаряд із системи залпового вогню БМ-21 "Град"

Якщо 3 моменту падіння снаряду дощу ще не було, то потрібно зняти приблизно 10-15 см землі з середини воронки і в радіусі 3-4 м від неї. Якщо воронка велика - до 10 м, то краще зняти землю в радіусі 4-5 м від неї. 
Відповідно до свідчень місцевих очевидців і військових бойовики використовували здебільшого міномети калібру 82 та 120 мм, артилерійські системи калібру 120 мм і потужніші калібром 152 мм, запалювальні міни, артилерійські та реактивні снаряди. Найбільшої шкоди будівлям, грунту та різноманітним комунікаціям завдають фосфорні боєприпаси, оскільки бойова зброя, що містить білий фосфор, поширює запалювальну сполуку. При цьому температура горіння перевищує $800{ }^{\circ} \mathrm{C}$. Фосфорні бомби бойовики почали використовувати 17.05.2015 р., стріляючи по укріпленнях захисників у Пісках та в ніч 318 на 19 травня по житловому кварталу Пісків.

Після припинення воєнних дій та розмінування території потрібно виконати комплекс робіт з відновлення земель - рекультивацію [12, 13]. Рекультивацію земель, порушених внаслідок воєнних дій, проводять у два етапи: технічний i біологічний $[14,15]$. Суть технічного етапу полягає у підготовці територій для наступного цільового використання. Він полягає у плануванні, а також нанесенні грунтів або родючих порід на вирівняну поверхню. Біологічний етап - це комплекс заходів щодо відновлення родючості порушених земель. Він охоплює агротехнічні й меліоративні заходи, які спрямовані на поновлення флори й фауни.

Технічний етап передбачає: зняття грунту і транспортування; ввіз грунту; засипання воронок, ліній укріплення, траншей; розбирання дерев'яних і залізобетонних конструкцій; засипання бліндажів грунтом 3 наступним плануванням; вжиття протиерозійних заходів на еродованих ділянках і територіях, засипання ярів; планування поверхні і нанесення родючого шару з наступним збагаченням мінеральними й органічними добривами.

Треба зазначити, що покриття порушених територій шаром родючого грунту обмежується економічними та соціальними умовами. На цій території порушені ділянки, що виникли внаслідок "точкових" впливів на довкілля. Досить багато $€$ воронок, для яких немає потреби робити складні й дорогі роботи з нанесення родючого шару, навіть якщо поблизу є запаси такого грунту. Ці воронки віднесено до об'єктів, що перебувають в умовах самозаростання. Потреба у нанесенні шару родючого грунту виникає на більших порушених територіях, де повсюдно розташовуються лінії укріплень, траншеї, що виявляють безпосередній вплив на процеси зміни стану природних комплексів.

Біологічний етап потрібно розпочинати з урахуванням таких умов: особливостей мікроклімату; фізико-хімічних властивостей грунтів; природного процесу самозаростання. У зв'язку з цим, можна використати такі напрямки біологічної рекультивації: сільськогосподарська (відновлення порушених земель для використання їх під ріллю, луки, пасовища, сінокоси, ягідники, сади); лісогосподарська (створення на відновлюваних землях лісонасаджень, лісозахисних смуг, протиерозійні насадження, лісові розсадки і лісові культури) [16].

Біологічний етап рекультивації охоплює: добір із числа місцевих видів флори асортиментів рослин, озеленення й створення найбільш продуктивних насаджень, регулювання самозаростання у потрібному напрямку, лісомеліорація і фітомеліорація, розроблення економічно ефективних способів створення фітоценозів. Треба зазначити, що залежно від характеру порушеності території, рекомендують різні заходи щодо відновлення цієї території (рис. 2).

\begin{tabular}{|c|l|}
\hline Нильно порушені & $\begin{array}{l}\text { Меліорація (лісомеліорація, агролісомеліорація, осушення } \\
\text { заболочених земель) Благоустрій (терасування схилів) }\end{array}$ \\
\hline Порушені & $\begin{array}{l}\text { Благоустрій (створення зелених і санітарних зон) } \\
\text { Меліорація (агролісомеліорація) }\end{array}$ \\
\hline Нлабко порушені & $\begin{array}{l}\text { Благоустрій (озеленення) } \\
\text { Меліорація (лісомеліорація, гідромеліорація, агролісомеліорація) }\end{array}$ \\
\hline Непорушені & Благоустрій (озеленення) \\
\hline
\end{tabular}

Рис. 2. Рекомендовані заходи відновлення порушених територій Донбасу

Як видно з рис. 2, залежно від характеру порушення території пропонують різноманітні заходи з ії відновлення, на які істотно впливає ступінь порушення, умови формування процесів саморегуляції та самовідновлення природної екосистеми.

Висновки. Отже, розпочати глобальне зачищення зони АТО від мін 3 наступним відновленням нормального життя та сільськогосподарської діяльності буде можливо тільки після того, як повністю завершаться бойові дії і буде підписана мирова угода. Для цього потрібно розробити зведену мапу мінних полів, провести розмінування території та подальшу рекультивацію. Рекультивацію територій, порушених внаслідок воєнних, дій потрібно проводити у два етапи: технічний і біологічний. Свої плани повинні передати обидві ворогуючі сторони конфлікту.

\section{Література}

1. Радовенчик В.М. Тверді відходи: збір, переробка, складування / В.М. Радовенчик, М.Д. Гомеля. - К. : Вид-во "Кондор", 2010. - 552 с.

2. Довгуша В.В. Война XX века. Экологическое жертвоприношение / В.В. Довгуша, М.Н. Тихонов // Энергия: Экономика. Техника. Экология : сб. науч. тр. - 1994. - № 9. - С. 19-23. 3. Для повного розмінування Донбасу знадобляться десятиліття - спецрепортаж 3 передової. [Електронний ресурс]. - Доступний 3 http://fakty.ictv.ua/ua/index/view-media/id/90513. 4. Розмінування Донбас. [Електронний ресурс]. - Доступний http://uisgda.com/novunu/424-rozminuvannya-donbas/.

5. На разминирование Донбасса уйдут десятки лет. [Электронный ресурс]. - Доступный с http://vesti-ukr.com/donbass/94552-na-razminirovanie-donbassa-ujdut-desjatki-let.

6. Сдиний в Україні Центр розмінування Збройних Сил продовжує готувати саперів для усіх силових структур. [Електронний ресурс]. - Доступний 3 http://ye.ua/news/news_17150.html.

7. До розмінування Донбасу залучатимуть міжнародні організації- ОБСС. [Електронний pecypc]. - Доступний 3 http://www.radiosvoboda.org/content/news/26936892.html.

8. "Піротехнічні підрозділи ДСНС України щоденно знаходять "неприємні сюрпризи" на звільнених територіях Донбасу" / Сергій Бочковський. [Електронний ресурс]. - Доступний з http://cn.mns.gov.ua/news/2021.html

9. ДСНС і ОБСЕ уклали договір про постачання техдопомоги для розмінування Донбасу. [Електронний ресурc]. - Доступний 3 http://www.rbc.ua/ukr/news/gschs-obse-zaklyuchili-dogovorpostavke-tehpomoshchi-1438249508.html.

10. ДСНС: піротехніки почали розмінування сільськогосподарських ділянок на Донбасі. [Електронний ресурс]. - Доступний 3 http://www.radiosvoboda.org/content/article/26927602.html. 11. В Донецькому аеропорту дуже багато. [Електронний ресурс]. - Доступний 3 http:// www.unian.ua/war/1063401-v-donetskomu-aeroportu-duje-bagato-boepripasiv-scho-ne-vibuhnuliobse.html.

2. Екологія та довкілля 
12. Пляцук Л.Д. Відновлення грунтів, порушених у ході війни в Іраку / Л.Д. Пляцук, Н.I. Аліяс // Екологічна безпека : зб. наук. праць. - 2012. - № 2 (14). - С. 37-40.

13. Пляцук Л.Д. Исследование грунтов в зоне военных действий Ирака / Л.Д. Пляцук, Л.Л. Гурец, Алияс Насер Ибрагим // Наука и образование Южного Казахстана : сб. науч. тр. 2012. - № 3/4 (94/95). - С. 193-198.

14. Панас Р.М. Рекультивація земель : навч. посібн. / Р.М. Панас. - Львів : Вид-во "Новий світ", 2007. - 224 с

$47 \mathrm{c}$.

15. Федосеева Т.П. Рекультивация земель / Т.П. Федосеева. - М. : Изд-во "Колос", 1997. -

16. Кучерявий В.П. Рекультивація та фітомеліорація : навч.-метод. посібн. В.П. Кучерявий, Я.В. Геник, А.П. Дида, М.М. Колодко. - Львів : Вид-во ГАФСА, 2006. - 117 с.

Тарнавский А.Б., Хромяк У.В. Привлечение подразделений Государственной службы по чрезвычайным ситуациям к разминированию и рекультивация территорий, нарушенных вследствие военных действий на востоке Украины

В настоящее время одной из основных характеристик техногенного воздействия на окружающую среду в Восточной Украине являются долговременные военные действия, которые приводят к негативным изменениям в окружающей среде. Проблема разминирования территорий проведения боевых действий и утилизации неразорвавшихся боеприпасов является достаточно острой. Проанализированы основные негативные послерс лас пен зационные мероприял по их обезвреживанию. Приведены информационные данные о наличии в ночве некоторых населенных пунктов Донбасса иоксичных тяжелых металлов после проведения артиллерийских обстрелов. Предложен основной комплекс работ по восстановлению разрушенных территорий.

Ключевые слова: военные действия, Восточная Украина, мины, минные поля, разминирования, пиротехнические подразделения, тяжелые металлы, загрязнение, почва, рекультивация, окружающую среду.

Tarnavskyj A.B., Khromyak U.V. The Implication of the State Emergency Service Units to Demining and Reclamation of Disturbed Areas in the Result of Hostilities in the East of Ukraine

Nowadays one of the main characteristics of anthropogenic impact on the environment in Eastern Ukraine is long-term military actions that lead to negative changes in the environment. The problem of demining conduct of hostilities and disposal of unexploded ordnance is very acute. Main negative effects of militants' mines and shells are analysed. Some basic or ganizational arrangements for their disposal are given. Some data concerning availability of toxic heavy metals in the soil of Donbas settlements after the shelling are provided. The main works on restoration of the destructed territory is presented.

Keywords: warfare, Eastern Ukraine, mines, minefields, mine clearance, pyrotechnic units, heavy metals, pollution, soil, reclamation, environment.

\section{3. ТЕХНОЛОГІЯ ТА УСТАТКУВАННЯ}

УДК 674.04 Проф. Б.Я. Кшивецький, д-р техн. наук-НЛТУ Украӥни, м. Львів ПРОГНОЗУВАННЯ ДОВГОВІЧНОСТІ ТЕРМОПЛАСТИЧНИХ КЛЕЙОВИХ З'ЄДНАНЬ ДЕРЕВИНИ БЕРЕЗИ

Проаналізовано методи та методики дослідження та прогнозування довговічност клейових з'єднань деревини. Запропоновано довговічність термопластичних клейових з'єднань деревини берези прогнозувати за допомогою математичної моделі, яка враховує коефіцієнт на породу деревини. Здійснено прогнозування довговічності термопластичних клейових з'єднань деревини берези залежно від умов експлуатації за допомогою математичної моделі. Проаналізовано отримані результати прогнозування довговічності та встановено, Шо за підвиненої температури навколишнгого середовише довгос- ність термопнастинни полівінілацетатних клейових з'сднань шується, а за підвищеної вологості навпаки - довговічність незначно зростає.

Ключові слова: клей, деревина, довговічність, вологість, температура, клейов з'єднання, прогнозування, водостійкість, теплостійкість.

На сучасному етапі розвитку деревообробної промисловості проблема довговічності стає дедалі актуальнішою, оскільки світові запаси деревини зменшуються, а потреба в склеєних елементах, конструкціях та виробах збільшується. Довговічність клейових з'єднань деревини характеризується границею міцності або напруженням, за яких настає руйнування.

Під довговічністю розуміють забезпечення клейовим з'єднанням 3 деревини відповідної адгезійної та когезійної міцності протягом певного часу або до виконання певного обсягу роботи. Довговічність термопластичних клейових з'єднань деревини, як і будь-яких інших клейових з'єднань буде залежить від багатьох факторів, основними серед яких є: властивості матеріалу, що склеюється (деревини), властивості клею, технологічні параметри процесу склеювання; умови експлуатації тощо $[1,2]$. Основні фактори впливу на довговічність клейових з'єднань деревини наведено на рис. 1. Процес дослідження довговічності клейових з'єднань деревини є тривалим і трудомістким та потребує відповідних методів та методик, певного устатковання тощо.

Довговічність клейових з'єднань деревини досліджують за тривалим (природним) та пришвидшеним (лабораторним) методами. Тривалий метод у природних умовах вважають найбільш достовірними, оскільки його результати відображають реальні процеси, які відбуваються у клейовому з'єднанні [3]. Paзом 3 тим, результати таких досліджень $є$ достовірними для певної кліматичної зони або району, тривалі у часі, потребують математичної оброблення та не дають змоги за короткий проміжок часу дослідити вплив окремих факторів.

Пришвидшений метод досліджень довговічності клейових з'єднань зводиться до створення умов із різкими перепадами температури і вологи. Він $\epsilon$ менш громіздким, зменшує тривалість досліджень, дає змогу вивчати вплив окремих факторів на клейові з'єднання, порівнювати результати досліджень тощо.

Під прогнозуванням довговічності клейових з'єднань деревини розуміють передбачення зміни вихідних характеристик з'єднання за довготривалої 